\section{Greetings from the editor}

\author{
Josef S Smolen
}

Since the time I had the privilege to take over the editorship of the ARD from Tore Kvien, I have provided biannual 'Greetings from the editor'. By convention, greetings in the January issues focused on the preceding year's evolutions and future plans for ARD, coupled with best wishes for a happy new year; and in the June issues, on the occasion of the Annual EULAR Congresses, the Greetings comprised an update on the most recent and current content of the Journal and also wishes for a successful Congress. Alas, last year, for the first time in its history, the EULAR Congress had to take place virtually and this year again, we will not have the opportunity to meet at the conference site face to face. The COVID-19 pandemic prevents us from sitting in large lecture halls with many other participants, engaging in personal discussions with speakers and other colleagues, seeing each others' smiles and body language and getting together socially.

Exactly a year ago, I ended my greetings saying: 'Let us hope that an effective therapy and vaccine against COVID-19 will be developed in due course'. ${ }^{1}$ And much to my surprise, by the time of my January 2021 greetings, the first vaccine had shown good efficacy and safety in clinical trials ${ }^{2}$ and soon thereafter it was approved; other vaccines swiftly followed. While effective therapies that prevent COVID-19 are not yet in sight, the vaccines were developed in record time.

The COVID-19 pandemic is reminiscent of other pandemic and epidemic situations. Indeed, about 100 years ago, the influenza pandemic of 1918-1920 cost more lives than World War I. It took 15 years from the time of that pandemic to isolate the virus. ${ }^{3}$ Burnet, recipient of the Nobel prize for physiology and medicine in 1960 for his contribution to the elucidation of acquired immunological tolerance, and who is likely best known to rheumatologists for his clonal selection theory of antibody production, ${ }^{4}$ was the first to cultivate the influenza virus on developing hen eggs in $1935 .^{5}$ With his continuing research, ${ }^{6}$ this achievement ultimately enabled developments that

Division of Rheumatology, Department of Medicine 3, Medical University of Vienna, Vienna, Austria

Correspondence to Dr Josef S Smolen, Medical University of Vienna, 1090 Wien, Austria; josef.smolen@meduniwien.ac.at culminated in the production and successful application of influenza vaccines almost a decade later. $^{78}$

Why is influenza mentioned here? First, because it provoked a similarly fatal pandemic 100 years ago as SARS-CoV-2 has today. Second, because it has been proposed to occasionally elicit autoantibodies like rheumatoid factor and antiphospholipid antibodies, ${ }^{9}$ observations that also have been reported for patients with COVID-19 in ARD recently. ${ }^{10} 11$ Third, because we have learnt in previous studies that disease modifying antirheumatic drugs, including tumour necrosis factor (TNF) inhibitors, interfere with the efficacy of influenza vaccination only to a small extent, ${ }^{12}$ while rituximab has significant effects in this respect. ${ }^{13}$ These and other pieces of information are contained in a timely update of EULAR recommendations regarding vaccinations last year ${ }^{14}$ but also most recently in EULAR points to consider for the current SARS-CoV-2 vaccination programmes published in this issue. ${ }^{15}$ And fourth and finally, because the example of a single personality, a pillar and hero across many areas of medicine, Sir Burnet reveals how closely related research into infectious disease and investigations of immunological mechanisms are.

When Burnet received the Behring Award of the University of Marburg/Lahn on 15 March 1954, he mentioned his esteem for Emil von Behring, ${ }^{16}$ a 1901 Nobel laureate (actually the first to be awarded this prize for medicine), who had detected the therapeutic value of 'anti-toxins', extracted from sera of immunised animals, against diptheria and tetanus and founded a manufacturing plant for these sera, the 'Behringwerke'. However, Burnet particularly praised Paul Ehrlich because in his view Ehrlich, like nobody else into Burnet's days, had brought microbiology, immunology and chemotherapy (in the sense of antimicrobial therapy such as against syphilis) together. ${ }^{16}$ Indeed, Ehrlich, himself a Nobel laureate (1908), by having developed the 'side chain theory' of antibody production ${ }^{17}$ and having invented the term 'horror autotoxicus' (ie, fear of selfdestruction) as a first historic discrimination of self and non-self and thus recognition of tolerance, is one of the founders of modern immunology. All these foundations within the field remain relevant in current therapeutic approaches: convalescent serum, monoclonal antibodies against SARS-CoV-2 spike protein and vaccination with spike protein are exploratory or approved and effective therapeutic or preventive options. Moreover, medicines that are part of the rheumatologists' armamentarium appear to be efficacious against severe COVID-19. ${ }^{18} 19$

This excursion to Burnet, Ehrlich and Behring should remind us that epidemics and pandemics have been around since times past-obviously already much before the 20th century, such as the plague-and were ultimately successfully conquered. It also allows the forming of a coordinated response, such as that which arose at the beginning of the 20th century with the foundation of the Behringwerke, to produce animal sera against various toxins and vaccines against typhoid and tetanus, and closes with the takeover of the Behringwerke by BioNTech ${ }^{20}$ to produce their vaccine against SARS-CoV-2, the first COVID-19 vaccine to be licensed; one of several vaccines that serve, among many others, our patients.

In a treatise on rheumatic fever, yet another belatedly recognised consequence of an epidemic with particular rheumatological impact ${ }^{21} 22$ that has only become controllable with the widespread availability of antibiotics, Copeman stated over 75 years ago in ARD that 'clinical medicine is the study of man in his enviroment'. ${ }^{23}$ To present, studies on people with rheumatic and musculoskeletal diseases to understand the value of novel therapies, develop insights into diagnostics and outcomes assessments, enlighten aetiology and pathogenetic pathways, has been and continues to be the focus of ARD since its foundation in 1939. Adherence to these principles is also visible in this issue.

Several points-to-consider or recommendations are presented in this June issue: one on the pathophysiology of COVID-19 (accompanied by an elegant editorial) ${ }^{24} 25$; one on the important topic of adherence to treatment ${ }^{26}$; and one on the standardisation of scoring in arthritis models, an area where standardisation had not been undertaken hitherto. ${ }^{27}$ A review authored by one of the world's premier groups provides an important summary of current knowledge and prospects on functional genomics. ${ }^{28}$

In the 'Heroes and Pillars of Rheumatology' section, eminent authors remind us of two major figures in rheumatology of the late 20th century into the most recent years, Charles L Christian and Joachim R Kalden, a US and a European hero, respectively, who have inspired the whole world with their research and personalities. ${ }^{29} 30$ These remarkable leaders were among the most important scientific and clinical pillars of modern rheumatology, mentoring 
numerous rheumatologists, including chairpersons of rheumatology departments who are active in our current day, and both having been Presidents of the respective major organisations across the Atlantic, namely, ACR and EULAR.

As always, this issue also presents many original research papers and letters, together with the correspondence section. In this issue, some focus is given again to COVID-19, COVID-19 which has become a major research focus for rheumatologists and which has interfered with all our lives over these past 15 months. Enjoy reading these and the other papers.

With the 2021 Congress, the EULAR Presidency of Professor Iain McInnes will end. With his dedication and his immense spirit to advance the impact of the organisation, he has steered EULAR splendidly through difficult and, sometimes surreal, times. The creation of a virtual research center $^{31}$ during his term of office will help to further advance the field and likely become a source of inspiration and important manuscripts to be submitted to major scientific journals such as ARD. Thrown into the virtual reality of an EULAR Congress, he and his team have already made the 2020 Congress a very special, very successful and, in many ways, a memorable event, while the plans for this year's event will fully materialise as you read these Greetings. His support for ARD, both as associate editor and reviewer, was exemplary and is acknowledged thankfully. The Presidency moves to Professor Annamaria Iagnocco who is cordially welcomed and under whose leadership EULAR will further prosper and flourish! During her term of office, EULAR will hold its 75th anniversary next year and we all already now look forward to this celebration.

Let me close by wishing, as we all do, that the pandemic will soon be under full control. Let me also wish you an inspiring and successful EULAR 2021, and let us hope that we will meet in person and in joy again for EULAR 2022.

Kind regards

Josef Smolen

Funding The authors have not declared a specific grant for this research from any funding agency in the public, commercial or not-for-profit sectors.

Competing interests None declared.

Patient and public involvement Patients and/or the public were not involved in the design, or conduct, or reporting, or dissemination plans of this research.

Patient consent for publication Not required.

Provenance and peer review Commissioned; internally peer reviewed.

\section{(2)} OPEN ACCESS

Open access This is an open access article distributed in accordance with the Creative Commons Attribution Non Commercial (CC BY-NC 4.0) license, which permits others to distribute, remix, adapt, build upon this work non-commercially, and license their derivative works on different terms, provided the original work is properly cited, appropriate credit is given, any changes made indicated, and the use is non-commercial. See: http:// creativecommons.org/licenses/by-nc/4.0/.

(c) Author(s) (or their employer(s)) 2021. Re-use permitted under CC BY-NC. No commercial re-use. See rights and permissions. Published by BMJ.

\section{A) Check for updates}

To cite Smolen JS. Ann Rheum Dis 2021;80:677-678.

Received 20 April 2021

Accepted 20 April 2021

Ann Rheum Dis 2021;80:677-678.

doi:10.1136/annrheumdis-2021-220608

\section{REFERENCES}

1 Smolen JS. Greetings from the editor. Ann Rheum Dis 2020;79:677-8.

2 Smolen JS. Greetings from the editor 2021. Ann Rheum Dis 2021;80:1-3.

3 Andrewes C, Laidlaw PP, Smith W. The susceptibility of mice to the viruses of human and swine influenza. Lancet 1934;224:859-62.

4 Burnet FM. A modification of Jerne's theory of antibody production using the concept of clonal selection. Aust J Sci 1957;20:67-9.

5 Burnet FM. Propagation of the virus of epidemic influenza on the developing egg. Med J Aust 1935;2:687-9.

6 Burnet FM, Bull DH. Changes in influenza virus associated with adaptation to passage in chick embryos. Aust J Exp Biol Med Sci 1943;21:55-69.

7 Hirst GK, Rickard ER, Whitman L, et al. Antibody response of human beings following vaccination with influenza viruses. J Exp Med 1942;75:495-511.

8 Francis T, Salk JE, Pearson HE, et al. Protective effect of vaccination against induced influenza A. J Clin Invest 1945;24:536-46.

9 Ulvestad E, Kanestrøm A, Tengnér P, et al. AntiCardiolipin autoantibodies and pulmonary embolism. A case for a common cause. Scand I Rheumatol 2000;29:330-3.

10 Vlachoyiannopoulos PG, Magira E, Alexopoulos H, et al. Autoantibodies related to systemic autoimmune rheumatic diseases in severely ill patients with COVID-19. Ann Rheum Dis 2020;79:1661-3.

11 Amezcua-Guerra LM, Rojas-Velasco G, Brianza-Padilla $\mathrm{M}$, et al. Presence of antiphospholipid antibodies in COVID-19: a case series study. Ann Rheum Dis 2021:80:e73.

12 Fomin I, Caspi D, Levy V, et al. Vaccination against influenza in rheumatoid arthritis: the effect of disease modifying drugs, including TNF alpha blockers. Ann Rheum Dis 2006;65:191-4.

13 Oren S, Mandelboim M, Braun-Moscovici Y, et al. Vaccination against influenza in patients with rheumatoid arthritis: the effect of rituximab on the humoral response. Ann Rheum Dis 2008;67:937-41.

14 Furer V, Rondaan C, Heijstek MW, et al. 2019 update of EULAR recommendations for vaccination in adult patients with autoimmune inflammatory rheumatic diseases. Ann Rheum Dis 2020;79:39-52.

15 Bijlsma JWJ. EULAR December 2020 viewpoints on SARS-CoV-2 vaccination in patients with RMDs. Ann Rheum Dis 2021;80:411-2.

16 BURNET FM. [On hemagglutination and genetics of the influenza virus]. Dtsch Med Wochenschr 1954;79:737-9.

17 Ehrlich P, Morgenroth J. Die Seitenkettentheorie der Immunität (The side chain theory of immunity). Anleitung zu hygienischen Untersuchungen : nach den im Hygienischen Institut der königl LudwigMaximilians-Universität zu München üblichen Methoden zusammengestellt. 3 edn, 1902: 381-94.

18 Ramiro S, Mostard RLM, Magro-Checa C, et al. Historically controlled comparison of glucocorticoids with or without tocilizumab versus supportive care only in patients with COVID-19-associated cytokine storm syndrome: results of the chiC study. Ann Rheum Dis 2020;79:1143-51.

19 Kalil AC, Patterson TF, Mehta AK, et al. Baricitinib plus Remdesivir for hospitalized adults with Covid-19. N Engl J Med 2021;384:795-807.

20 redaktion@deutsche-apotheker-zeitung.de.Von behring zu biontech - impfstoff-hoffnung auf historischem grund (from behring to biontech vaccine-hope at historic grounds), 2020. Available: https://www deutsche-apotheker-zeitung de/ news/artikel/2021/01/14/impfstoff-hoffnung-aufhistorischem-grund [Accessed $24 \mathrm{Mar} 2021$ ].

21 Glover JA, Griffith F. Acute tonsillitis and some of its sequels: epidemiological and bacteriological observations. Br Med J 1931;2:521-7.

22 Coburn AF, Pauli RH. Studies on the relationship of Streptococcus hemolyticus to the rheumatic process. J Exp Med 1932;56:609-32.

23 Copeman WS. Observations on the natural history of acute rheumatic fever. Ann Rheum Dis 1944:4:11-21.

24 Alunno A, Najm A, Machado PM, et al. EULAR points to consider on pathophysiology and use of immunomodulatory therapies in COVID-19. Ann Rheum Dis 2021:80:698-704.

25 Calabrese L, Winthrop KL. Rheumatology and COVID-19 at 1 year: facing the unknowns. Ann Rheum Dis 2021;80:679-81.

26 Ritschl V, Stamm TA, Aletaha D, et al. 2020 EULAR points to consider for the prevention, screening, assessment and management of non-adherence to treatment in people with rheumatic and musculoskeletal diseases for use in clinical practice. Ann Rheum Dis 2020;80:707-13.

27 Hayer S, Vervoordeldonk MJ, Denis MC, et al. 'SMASH' recommendations for standardised microscopic arthritis scoring of histological sections from inflammatory arthritis animal models. Ann Rheum Dis 2021;80:714-26

28 Suzuki A, Guerrini MM, Yamamoto K. Functional genomics of autoimmune diseases. Ann Rheum Dis 2021;80:689-97.

29 Crow MK. Charles L Christian: model physician scientist and mentor. Ann Rheum Dis 2021;80:685-8.

30 Burmester G-RR, Manger B, Schett G, et al. Joachim Robert Kalden (1937-2021): one of thefounders of autoimmunity researchand immunotherapy. Ann Rheum Dis 2021:80:682-4.

31 EULAR. EULAR virtual research center, 2020. Available: https://www eular org/eular_virtual_research_centre $\mathrm{cfm}$ 